\title{
Strengthening Public-Private Partnership in Sri Lanka's Infrastructure Development Project: The Colombo Port Case*
}

\author{
TAEKYOON KIM ${ }^{* *}$ • SANG JUN LEE ${ }^{* * *}$ - MANJULA PRADEEP ${ }^{* * * * *}$
}

Infrastructure has been a key component to Sri Lanka's economic and social development especially through Public-Private Partnerships (PPP), but Sri Lanka is currently at a crossroads in term of fostering its PPP framework for infrastructure. This study sets out to examine and delineate the current landscape as well as the future prospects of Sri Lanka's PPP with the particular reference to the Colombo Port Expansion projects implemented since 1999 as a proxy for Sri Lanka's outlook of infrastructure PPP. It further contends that a given rule-of-thumb on PPP projects is not feasible in developing countries given their economic and political volatility, but positive changes in government strategies and policies can be suggested for better practices and effectiveness in Sri Lanka's infrastructure PPP. Rather than simply suggesting a positive-descriptive overview of the Colombo Port case, this study advances the proper management of the PPP unit as a critical juncture for strengthening the future landscape of Sri Lanka's PPP initiatives.

Keywords: Public-Private Partnership, Sri Lanka, Infrastructure, Colombo Port Expansion Projects, ADB, USAID

* This work was supported by the Ministry of Education of the Republic of Korea and the National Research Foundation of Korea (NRF-2018S1A3A2075117). Also, this work was sponsored by the Yulchon-GSIS Center for Emerging Economies, Seoul National University.

** Corresponding author, Associate Professor, Seoul National University, South Korea; E-mail: oxonian07@snu.ac.kr

*** Research Assistant, Seoul National University, South Korea; E-mail: sj1215@snu.ac.kr

**** Assistant Director of National Planning Department, Government of Sri Lanka; E-mail: manjulapss@yahoo.com DOI: 10.16934/isr.20.1.201906.91 


\section{INTRODUCTION}

To what extent would public-private partnership (PPP) play a significant role in pursuing infrastructure projects affecting social and economic development in developing countries? This study advances Sri Lanka as a classical case representing lower-middle-income countries where the national strategic planning for economic growth was backed by not instabilities of political regimes in transition processes, but positive outlooks of PPP despite concerns regarding financial measures and debt trap. The political decay and its entailing instability in Sri Lanka's political governance led the government to rely on and advocate PPP as a viable and sustainable measure to address national development issues. ${ }^{1}$

Indeed, infrastructure has been one of the key components to Sri Lanka's economic and social development especially through PPP. The growing importance of PPP was recognised in the late 1990s with various PPP-related institutions being established within the 1998 PPP Guidelines Part II. With the 10 Year National Plan of Action (NPA) 2015-2025 enacted, increased levels of PPP are expected to complement the New Long-Term Strategic Framework of ADB 2008-2020 and New South Asia Sub-regional Economic Cooperation (SASEC) Operational Plan 2016-2025. Thus, the main aim of this study is not only to review the past and present landscapes of Sri Lanka's PPP within the infrastructure sector in a critical way but also to identify how the infrastructure PPP contributed to its national economic development plans and what would be the factors to strengthen the successful implementation of PPP. ${ }^{2}$ This study uses the Colombo Port Expansion cases since 1999 as a proxy for Sri Lanka's outlook in infrastructure PPP. It further contends that a given rule-of-thumb on PPP implementation in Sri Lanka is not feasible in implementing it to developing countries given their economic and political volatility. Nevertheless, there are positive changes to government strategies and policies - particularly, the establishment of a PPP unit within the Ministry of Finance and Planning, which may provide a critical juncture for the future landscape of the country's PPP initiatives. Overall, Sri Lanka is currently at a crossroads in terms of fostering its PPP framework for infrastructure.

Ultimately, this study advocates that lessons learnt from the Colombo Port case need to be incorporated into Sri Lanka government's PPP plans via the newly devised PPP unit. By using the PPP unit as a platform to foster publicprivate relationship and trigger an autonomous PPP act, a strengthened PPP mechanism can be built. It is puzzling to ask why and how Sri Lanka, unlike many other developing countries suffering from inefficient and wasteful PPP contracts, has been successfully implementing PPP projects in the infrastructure sector. In order to provide adequate answers for the puzzling question above, this study is segmented into five main sections. The subsequent section includes a 
literature review of PPP theoretical frameworks and a brief introduction to Sri Lanka's infrastructure development. Then, three objectives are outlined, and the modality of methodology is provided. The proceeding section is the empirical analysis, which contains two sub-sections of case-study analysis and a synthesis of PPP development in the country. Finally, the conclusion section recalls all the key tenets of this paper, and pinpoints some aspects for further improvement.

\section{REVIEWS ON PPP FRAMEWORKS FOR INFRASTRUCTURE DEVELOPMENT}

For Sri Lanka, PPP is a relatively new concept, and thus, its framework is yet materialised within the country. Likewise, for most developing countries where the concept of PPP per se was spurred since the late 1990s, PPP in Sri Lanka has been initiated fairly recently with a degree of ambiguity. The main reason for this comes from the fact that the definition, modality and form of PPP are equivocal. According to the Asian Development Bank (ADB 2012a, 14), PPP is a "range of possible relationship among public and private entities in the context of infrastructure and other services." Whereas the UN $(2003,54)$ denotes PPP as "innovative methods used by the public sector to contract with the private sector," where the private sectors' responsibility is on capital and the delivery of the project, meanwhile, the public sector is accountable for the provision of the services in a manner in which the public can benefit. What is explicit here is that the definition of PPP is structured differently depending on the organisation. Thus, the key objective of this section is to elaborate on the core theoretical frameworks on PPP including definitions, constituents and different models available for practice; and finally, discuss how PPP is adopted in the infrastructure sector.

\section{Concept of PPP in Infrastructure Development}

A commonly adopted procurement strategy in both developed and developing countries is capturing private capital through PPP (Cook et al. 2004). As already touched upon, the definition of such strategy is contested. Accordingly, there is no standard method of PPP implementation as each country adopts the strategy in accordance with its own culture, economic and political climate as well as its legal system (Appuhami et al. 2011). Hence, when implementing PPP, it is crucial that all stakeholders have a 'common understanding' of the principles of PPP; in other words, an aligned set of guidelines (Perera 2016, 6-9). The use of PPP in the infrastructure sector is widespread primarily in the sense of the large amount of investment fund needed in the early stages of a project. Although PPP is used in a similar manner in other sectors, the main difference is that PPP in infrastructure development involves the participation of private sector either 
partially or fully in all phases of design, construction, financing and operation (USAID 2016).

It is fair to state that many academic and industrial practitioners concur that PPP is the most feasible strategy to adopt in order for governments to fulfil the widening demand-supply gap for infrastructure while meeting the 'social commitments within fiscal constraints' (Rashed et al. 2012). In this regard, PPP enables the government to support public services without straining public funds, which are primarily from taxation. Furthermore, main features of PPP fold in four: (1) efficiency gains via risk diversification (whilst the public sector retains sovereignty); (2) the lifecycle of an infrastructure project being shaped by the private investment; (3) the time-frame of PPP described typically as a long term contractual relationship between the public and private sector; and (4) flexibility in terms of infrastructure operations, which includes output specification and payment mechanisms (Sharma 2012). These four features of PPP affect one another, and subject to changes depending on the country as well as the type of contract that the government is pursuing.

The vagueness of PPP's definition involves not only the lack of standardised formality when it comes to the degree of private sector influence and autonomy but also its entailing divergence of PPP options according to the extent of private sector participation (see figure 1) (Narangoda and Khathibi 2014; Traupel 2009). Through PPP, government's responsibilities are outsourced to private sector partners, thereby risks being shared. However, with regards to accountability, such contractual partnership may hinder clarity on the role of responsibilities among stakeholders (Kim and Lim 2017). Also, it must be pointed out that PPPs go beyond the conventional cooperation between the public and private sector as a basic contractual form. Depending on the type of partnership, PPP schemes allow the private sector to gain control over a certain facility or operation of infrastructure usually for a long period of time that is agreed and specified in the contract (USAID 2016). The time frame specified is usually proactively derived in order for the private sector to sufficiently recover construction and maintenance costs of the project, and is expressed as the rate of return on investment in business terms (World Bank 2015). The mode of private sector recovering its costs is usually in tariffs or tolls.

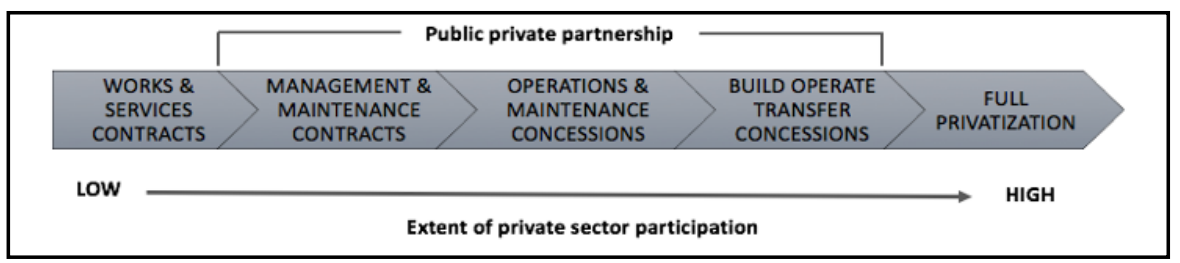

Source: IBRD (2017).

FIGURE 1. PPP OPTIONS 
Although the types of model and contract are different for most PPP frameworks, they all fall under the umbrella of either horizontal or vertical partnership (Alfen 2009; Alfen et al. 2009; Narangoda and Khathibi 2014). The former refers to both parties engaging directly as shareholders, and thus, PPP plans in a horizontal partnership are occasionally referred to as 'Joint Projects.' On the other hand, vertical partnership where the private partner provides required services under a PPP contract is usually called a concession agreement. Hence, vertical partnership is also referred to as contractual PPP; and horizontal partnership is also known as institutional PPP (Rashed et al. 2012). Generally, in a horizontal partnership, the public sector has medium to high level of control on the project and the operations of the infrastructure. Consequently, most governments in developing countries favour the horizontal type of partnership. However, due to the fact that it requires policy and business coherence from both public and private sector, it takes time and is costly. Furthermore, while risks are explicitly separated among parties in vertical partnership, risks, roles and responsibilities at times are obscured under horizontal PPPs. Both types of partnership have pros and cons, which lead different countries to adopt different types for a certain project.

What complicates the nature of PPP is not merely regarding the range of type and model of PPP. According to the characteristics of the partnership, the processes of implementing PPP framework change. Figure 2 depicts the standard processes of a typical PPP framework. The preparatory and procurement phases of PPP are relatively short (usually up to a year), considering how PPPs are implemented for long-term purposes. The relative swiftness in finalizing the two phases depends on whether the country adopts a 'PPP law' or has an independent 'PPP department.' In Sri Lanka's case, a specific PPP law is absent, which means the two phases - notably the preparation phase - are considered weak in comparison to the neighbouring countries (World Bank 2015). The monitoring phase takes place until the end of contract with both ex-ante and ex-post evaluation conducted by a third party. The point to emphasise is that since PPP schemes are long-term in nature, there needs to be a room for flexibility for partnership arrangements to respond to external circumstances such as bank-runs or swift changes in commodity prices.

\begin{tabular}{|c|c|c|}
\hline $\begin{array}{c}\text { Phase I } \\
\text { Preparation } \\
\text { Typical Duration: } 9-12 \text { months }\end{array}$ & $\begin{array}{c}\text { Phase II } \\
\text { Procurement } \\
\text { Typical Duration: 6-12 months }\end{array}$ & $\begin{array}{c}\text { Phase III } \\
\text { Monitoring } \\
\text { Typical Duration: Length of the } \\
\text { contract }\end{array}$ \\
\hline
\end{tabular}

Source: USAID (2016).

FIGURE 2. PHASES IN PPP 


\section{Erratic Development of Sri Lanka's PPPs for Infrastructure}

As Sri Lanka is a developing country within the low-middle income group, governments throughout the past two decades placed PPP as one of the key frameworks to adopt for infrastructure development. Especially since the end of the internal conflict in 2009, the governments were keen to implement policies that rapidly rehabilitated the country's growth via infrastructure. According to World Bank's Benchmarking PPP Procurement Team, infrastructure such electricity, water source, sanitation facilities as well as urban development in Sri Lanka have substantially improved during the past decade; over $90 \%$ of population currently has access to electricity, water and sanitation (World Bank 2015). However, Sri Lanka received a modest score at 2.23 (level 1 indicates a very low score, and level 5 indicates a very high score) in the 'Logistics Performance Index,' which includes the quality of trade and transport-related infrastructure including ports, roads and railroads. Despite endeavours to facilitate development in roads and ports $(50 \%$ according to Department of External Resources, as shown in figure 3) via PPP especially with the aid of ADB, the low score indicates that there is much room for improvement by a serious measure.

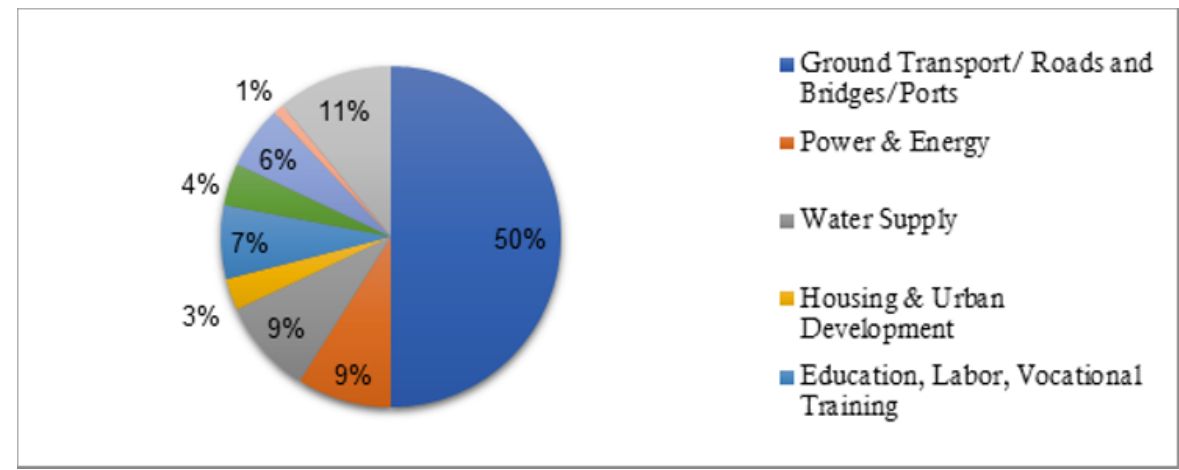

Source: Department of External Resources (2014).

\section{FIGURE 3. SECTORAL DISTRIBUTION OF FOREIGN FINANCING DISBURSEMENTS IN 2014}

The Sri Lanka Chamber of Commerce advocates for more investment in infrastructure. According to its comprehensive assessment of infrastructure investment needs, approximately $6.9 \%$ of GDP needs to be spent per annum in order to meet the need-demand on infrastructure from the public. As Sri Lanka is gradually shifting away from the low-income status to the middle-income status, less grants and concessional loans from aid donors are being handed. Thus, for the nation to utilise PPP as a mechanism to ease the financial burden on the 
public and meet the need for infrastructure development seems both a logical and feasible option.

Moreover, the Infrascope (2017) of the Economist Intelligence Unit conducts a cross-country research on a total of 40 developing countries regarding the enabling environment for PPPs. Scores 0 to 100 (a higher score denotes a PPP framework that closely aligns with internationally recognised good practices) are given to each of 40 countries for five different thematic areas of PPP: regulations, financing, institutions, maturity, and investment $\&$ business climate. As shown in figure 4, Sri Lanka's main weaknesses, which can be defined when the case corresponds to scores below the average, are placed in the four criteria of regulations (57/62), institutions (44/52), maturity (59/61) and investment \& business climate (56/59), except financing (44/43) only. Overall, Sri Lanka, as of February 2018, is ranked $26^{\text {th }}$ out of 40 developing countries, which remains at the 'emerging' stage of the enabling environment for PPPs. ${ }^{3}$ Although Sri Lanka has enhanced many facets of its national infrastructure increasingly adopting PPP frameworks, Infrascope's indicators show that infrastructure, particularly in the area of transport, needs significant improvement through progressive reforms in its PPP schemes that would incorporate internationally approved preparation and management practices.

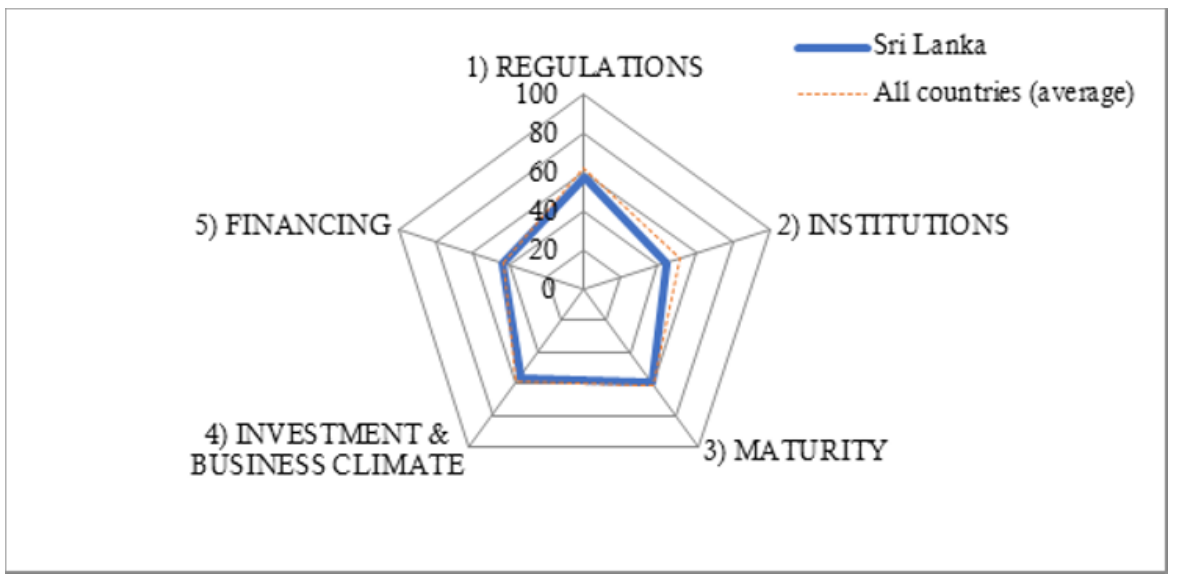

Source: Economist Intelligence Unit (2018).

\section{FIGURE 4. SRI LANKA'S ENABLING ENVIRONMENTS FOR PPP}

One of the contested points is whether Sri Lanka's PPP is adopted as a self-interested form of its own new public management (NPM) or an act of coercive policy diffusion from multilateral development banks such as the ADB and World Bank (Appuhami et al. 2011). The latter assertion explains how policy diffusion is seen as a unilateral process through "a process through which policy 
choices in one country affect those made in a second country" (Simmons and Zachary 2004, 171), and thus, requires a 'transfer agent' who influences recipients' decisions (Evans 2009). The main reason for these contending arguments results from the erratic nature of the development of Sri Lanka's PPP framework.

Since Sri Lanka gained independence from the British Empire, the country relied heavily on financial assistance from international financial institutions or multilateral development banks. Most assistance came with conditions, notably on how the market functions via structural adjustment programs - financial liberalisation and privatisation. As a result, despite the government of Sri Lanka being reluctant to privatise state-owned enterprises, especially those related to infrastructure facilities in mid-1992, the PPP policy was introduced through a cabinet decision (World Bank 2010). This policy was supported not only by multilateral banks, but also, bilateral aid agencies such as USAID. However, the policy underwent several changes mainly regarding the establishment of new units including the Secretariat for Infrastructure Development and Investment (SIDI) under the Ministry of Policy and Planning, and the Private Sector Infrastructure Development Company (PISDC) in 1995 (Appuhami et al. 2011). In 1996, the Bureau of Infrastructure Investment (BII) was established to replace SIDI and facilitate PPPs for infrastructure, receiving 77 million USD in financial assistance from the World Bank (Alfen 2009).

The subsequent critical juncture in the development of Sri Lanka's PPP initiative was in 2005, when the theme of the Annual Session of Sri Lanka Economic Association was "Public-Private Partnership for Development." Consequently, in 2006, the PPP unit was established within the Board of Investment (BOI), replacing BII with a stronger emphasis on carrying out transparent bidding processes (Sri Lanka Treasury 2017). With the continuous assistance from international organisations, Sri Lanka was able to enhance its PPP facilities. Furthermore, by hosting capacity-building forums such as the United Nations Economic and Social Commission for Asian and the Pacific (UNESCAP) and the Korean Development Institute's Asia Pacific Business Forum on Public-Private Partnership for Infrastructure Development, Sri Lanka was able to learn lessons from more advanced countries.

\section{THE ROLE OF PPP IN PORT EXPANSION CASES}

Conducting a comparative analysis on the two cases of Colombo Port projects (the 1999 Colombo Port Development Project and the 2007 Colombo Port Expansion Project) enables us to detect how the positive aspects of PPP in Sri Lanka's infrastructure sector have been forged. Exploring the two cases respectively comprises project summary, legislative environment, and key points 
of success. This provides the empirical basis for constructing a further strengthened PPP mechanism for the Colombo Port infrastructure projects.

\section{Colombo Port Development Project, 1999}

\section{1) Project Summary}

Colombo is the capital of Sri Lanka, the site of a large deep-water port. On the Southeast side of the island, the Colombo Port facilities include two terminals: Jaya Container Terminal (JCT) and Queen Elizabeth Quay (QEQ) (see figure 5). The throughput of container traffic for the terminals at the Colombo Port increased from fewer than 500,000 twenty-foot equivalent units (TEUs) in 1987 to over 1.5 million TEUs in 1997. However, in the mid-1990s, this growth was beginning to slow due to inefficiencies and delays because of outdated systems and equipment. Projections showed traffic volume levelling off in 2003 or 2004 when the maximum capacity for JCT - the larger and more active of the terminals - would be reached. In addition, estimates at the time indicated that around $40 \%$ of west-to-east traffic was diverted from the Colombo Port to more competitive ports outside of Sri Lanka. Regional trade traffic continued to grow, and forecasts at the time predicted an estimated $7.3 \%$ annual growth in traffic to India until 2018 and an overall increase in regional container traffic because of the increasing trade volume (UNDP 2007). Meanwhile, the Colombo Port was slowly losing its competitive edge to newer, more modern port facilities, and required capital investments for maintenance.

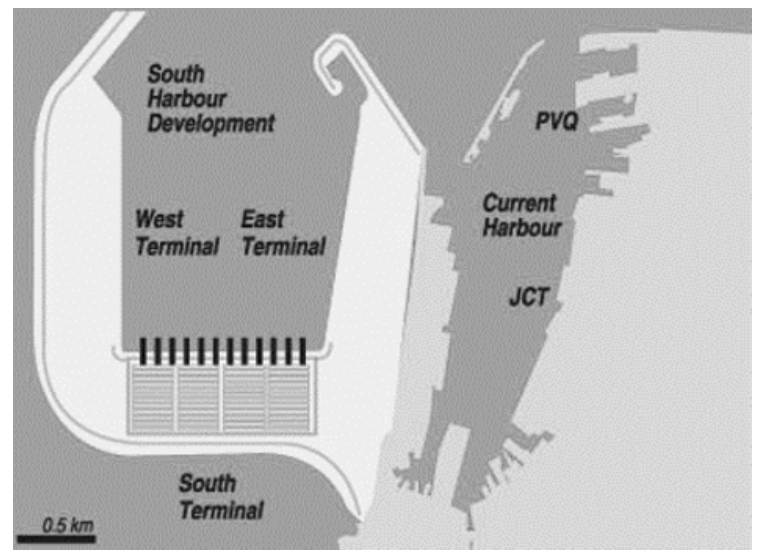

Source: SLPA (2017)

FIGURE 5. MAP OF THE COLOMBO PORT 
The government of Sri Lankan's desire to remain a strong competitor in the shipping sector prompted the creation of a PPP in 1999. The South Asia Gateway Terminals (Private) Limited (SAGT partnership) was established by the Sri Lanka Port Authority (SLPA) and a few private companies to improve, expand, operate, and manage the QEQ terminal through a 30-year Build-OperateTransfer (BOT) concession. In August of 2003, construction for the expansion of QEQ was completed. From 2000 to 2004 throughput for QEQ increased by 350 percent, leading to a "30 percent increase for Colombo Port as a whole" (SLPA 2017). Economic efficiency for the Port as a whole has improved because of management techniques utilised by the SAGT partnership at QEQ and in turn transferred from the SAGT partnership to JCT.

Since the inauguration of the project, the objectives were threefold. The first objective was to expand the QEQ terminal from the original capacity of 285,000 TEUs per year to a capacity of 1 million TEUs (ADB 2005). The expansion in the volume of trade handled by Sri Lanka would increase, generating revenue for the Port and broader economic benefits as well. Improving the Port efficiency was the second objective of the project. Sri Lanka's location gave it a competitive advantage in the ocean shipping industry in the region, but its competitive advantage, with a limited container capacity, would have disappeared. Efficiency needed to be improved in gross gantry moves (the number of containers handled) per hour. Berth efficiency, which measures the average waiting time for container vessels, also needed to be improved to achieve competitive advantage in the region. The third objective was to reveal to the international community and the private sector that PPP infrastructure projects could have positive outcomes in Sri Lanka. After the Asian financial crisis, and in response to internal political instability in Sri Lanka, private firms became too hesitant to invest in Sri Lanka. A strong and efficient project with the SAGT partnership showed the effectiveness of private sector involvements in infrastructure development sector and those significant benefits encouraged further investment in Sri Lanka.

\section{2) Legislative Environment}

In the 1970s, international financial institutions guided the liberalization of the Sri Lankan economy in order to promote its economic development in a more capitalist form. This included partnerships and private sector involvement in many facets of the economy. Since then, owe to a liberalized economy, Sri Lanka has witnessed increases in economic growth and a surge of foreign direct investment (FDI). Infrastructure development, renovation and expansion have featured prominently in these partnerships because the government has deliberately identified and prioritized infrastructure development as the main 
basic component of the economy.

As the government prioritized infrastructure development on its strategic agenda, on 31 January 1978, the Greater Colombo Economic Commission Law, No. 4 was enacted by the National State Assembly (Evans 2009). The Law enabled the establishment of the Greater Colombo Economic Commission (GCEC) to generate development in the outskirts of Colombo, and provided the GCEC with the authorities necessary for the management of PPP. The Law has been amended five times and the GCEC has been renamed as the BOI. The main objective of the BOI is to foster, generate, and strengthen the economy and to promote and attract foreign investment within the nation.

Since 1995, the Sri Lankan government has actively encouraged private sector participation in the development of port infrastructure through "partnerships in the form of either Build-Own-Operate (BOO) or Build-OperateTransfer (BOT) transactions" (UNDP 2007, 3). Under the unfavourable circumstances such as ports' limited capacity and rapid growth in the global shipping industry, the expansion of a port deemed necessary to maintain its competitive advantage. The Colombo Port, therefore, was selected for the expansion project since Colombo, as the capital of Sri Lanka, provided an ideal location in terms of shipping routes. Initially, the private sector was invited to bid for the development of an outer harbour for the Port, which required the construction of an expensive new breakwater structure because the Port did not have any necessary facilities and excess land for expansion.

Furthermore, Sri Lanka's government realised how vital infrastructure is to the economy, and hence, in 1996 the BOI established the BII to promote, attract and facilitate private sector investment in infrastructure sector development. The BII oversaw infrastructure, information technology, highways, housing, water, power, ports and solid waste sectors. A major milestone was reached in 1999 with the formation of the PPP SAGT to expand and operate the QEQ at the Colombo Port. The project allowed for the expansion within the existing port footprint and did not require costly upfront investment that would have been required to build a new breakwater structure. The 1999 Colombo port development project was the first transportation PPP project undertaken in Sri Lanka.

\section{3) Evaluation of Project Results}

Overall, the SAGT partnership has dramatically improved the efficiency of the Colombo port as well as QEQ. The container traffic has increased from 200,186 TEUs in 2000 to 899,720 TEUs in 2004, which means a 350 percent increase, with no net increase in QEQ staffing. Traffic was expected to continually rise, as there was a room for improvement to operate QEQ at full 
capacity. Berth efficiency has increased from an average of 6.9 hours of wait time for vessels in 1997 to 0.9 hours in 2003. As a result, total throughput, which included the transhipment volume at the Port, rose from "1.7 million TEUs in 1998 to 2.2 million TEUs in 2004 or by about 30\%" (ADB 2005).

Productivity at the Port has overall increased because SLPA adopted many of the same management techniques and strategies via the SAGT partnership. Approximately 500 jobs were created directly by the SAGT partnership and many other jobs were created as a result of contracts for maintenance at the expanded QEQ. Jobs in surrounding sectors have been created by increased spending by the SAGT partnership employees. With a greater number of vessels using the Colombo Port, demand for ancillary services in and around the Port incrementally increased. According to an ADB research, the economic internal rate of return, which measures the quantifiable net economic benefits to all of society, was over 15 percent for the life of the project, earning its contribution to economic development with a rating of 'excellent.' The project was evaluated by ADB's three main categories, such as development outcome, investment outcome, and effectiveness (ADB 2005).

Regarding the objectives, there were three main objectives of the project as mentioned before. The third objective of the partnership was to demonstrate its positive impacts on PPPs and private sector investment in Sri Lanka. In 2006, one of the partners in the SAGT partnership increased its holdings from 26.25 percent to 33.75 percent of the SAGT partnership's shares, thereby demonstrating its confidence in the SAGT partnership. The proposed project involved the building of a new terminal with three berths and a new breakwater. The criteria for submitting an Expression of Interest (EOI) to the government included having handled around 2 million TEUs, including at least 600,000 TEUs as transhipment in two terminals in the previous two years. Five companies, including the SAGT partnership, submitted EOIs, which signified their belief in the success of additional projects at the Colombo Port (UNDP 2007).

\section{Colombo Port Expansion Project, 2007}

\section{1) Project Summary}

In order to ascertain the sustainability of the Colombo Port, bringing and expanding modern shipping market practices to operations of the Colombo Port have become mandatory. The Colombo Port has numerous natural advantages in the sense that the Colombo Port has a well-protected deep-water harbour due to its location near the East-West trunk routes between the Asia-Pacific, Europe, and the United States East Coast regions. Its geographical advantageousness generated the closest transhipment port expanding the markets of the Indian 
Sub-Continent (ISC). For Europe-bound cargo for the East and South segments of the ISC, using the Colombo Port as a hub port was more advantageous than using Southeast Asian ports thanks to its shorter distance to India.

Hence, Sri Lankan government identified the importance of the port expansion and brought in modern shipping practices to the Colombo port. Therefore, at the request of the Sri Lankan government, ADB approved a loan of 300 million USD from its ordinary capital resources to finance the public sector component of the Colombo Port Expansion Project. The loan agreement on this PPP-based project was signed on 25 April 2007 and became effective on 2 May 2008 (ADB 2015). The purpose of this ADB-funded project was to assist the Sri Lankan government to consolidate Colombo Port's locational position as a transhipment hub for the South Asian region by providing sufficient containerhandling capacity and sufficient depth for new-generation vessels.

The project was expected to provide dredging and breakwater construction sufficient to accommodate three terminals that were to be constructed sequentially (South Container Terminal, East Container Terminal and West Container Terminal). It also included the relocation of a submarine oil pipeline, the establishment of a new marine operations centre, the provision of navigational aids, and the construction of shore utilities. The harbour infrastructure works (HIW) was implemented by the SLPA, and two terminals were constructed by private operators chosen through open competitive bidding under BOT concession agreements. The total cost of the project was estimated at 781 million USD comprising a public sector component of 480 million USD (about $61.5 \%$ of total cost) and private sector component of 301 million USD (about $38.5 \%$ of total cost). For the public sector component, a loan of 300 million USD from the ordinary capital resources of ADB were provided under ADB's London interbank offered rate (LIBOR)-based lending facility (ADB 2015, 1).

In this regard, the new project was implemented to promote economic growth by improving Sri Lanka's competitiveness in the port sector and facilitate economic prosperity by enhancing national competitiveness in international trade via lower transport costs and faster delivery times.

\section{2) Legislative Environment}

In the past decade, Sri Lanka has successfully harnessed PPPs for creating and improving infrastructure in several sectors including ports, power and telecom. The government interests in financing selected large scale infrastructure projects have been rekindled with Mahinda Chintana: Vision for a New Sri Lanka (Ministry of Finance and Planning 2006). This 10-year national strategy outlined the government intention to involve the private sector in infrastructure development as well as to improve the performance of state owned enterprises. The country's 
vision for port sector development, set out in Mahinda Chintana national policy, was as follows: (i) develop the main ports of the country to facilitate increasing export and import trade associated with rapid economic development of the country as well as the region by taking advantage of the liberalization and globalization process; (ii) decongest the Colombo Port by constructing South Port in Colombo, as well as the Galle and Hambantota ports; (iii) develop mediumscale ports in identified provinces such as South, East, and North to divert increasing volumes of domestic bulk freight transport from road to sea transport; (iv) encourage an alternative source of funding for new investment in portrelated infrastructure development; (v) operate ports as commercial entities without Exchequer support; and (vi) encourage PPP for new investment in the port sector. While continuing the state ownership of existing ports, the government strategy was to increase efficiency of existing ports, operate ports as commercial entities, and establish container terminals as PPP projects (Ministry of Finance and Planning 2006).

The BOI, structured to function as a central facilitation point for investors, was committed to continuously improve the country's investment climate. Based on the Public Utilities Commission of Sri Lanka Act 2002, Sri Lanka set up an independent multi-sector regulator, the Public Utilities Commission of Sri Lanka (PUCSL), to step into certain infrastructure sectors by changing the appropriate sector legislation. Until the passage of the Sri-Lanka Electricity Act 2009, the Act 2002 has still regulated the generation, transmission, distribution, supply, and use of electricity. Finally, reflecting the continuing role of PPPs in Sri Lanka, the Cabinet Subcommittee on Investment Promotion established a PPP Unit within the BOI in 2006. Since then, the PPP unit has been playing a great role in facilitating projects and providing procurement guidelines as well.

\section{3) Evaluation of Project Outcomes}

After a successful completion of the Colombo Port development in 1999, this project was evaluated as one of the largest PPP projects undertaken in Sri Lanka's ports sector. The public-sector investment for breakwaters has enabled investment for the three large-scale container terminals upon full completion to deliver an additional 7.2 million TEU of container-handling capacity per annum. The new facilities at South Container Terminal made it the only port in the South Asia region with a deep-water terminal that could accommodate the newest class of 18,000 TEU container ships (ADB 2015). They are currently the world's largest container ships and the most effective terminals that are able to operate for mainline shippers. Higher efficiency and faster delivery times would attract larger vessels and higher volume of trade, thereby enhancing Sri Lanka's competitiveness in international trade, and drawing investment to the country which would 
improve manufacturing and distribution centres. All in all, the new project contributed to bringing infrastructure benefits for the Sri Lankan economy both directly and through the multiplier effect of increased operation at the Port.

Such a success story attracted more private sector investments for the International Maritime Centre in Colombo and of the Port City Project, adjacent to the Colombo Port. The latter consisted of retail, residential, and office complexes, as well as other leisure and recreational activities that would promote further economic activity and growth. Regarding job creation, this project created both direct and indirect employment during the construction and operation period. A total of 1,950 jobs during construction were projected at appraisal. During the construction phase in 2011, the project employed 2,381 men and women, 307 of whom were foreign and 2,074 were local. The number of people employed locally "almost doubled in 2012 while the number of foreigners employed declined to 164" (ADB 2015, 12).

According to the ADB validation report, there was no serious negative impact through land acquisition and resettlement. At appraisal, this project was classified as Category C ("proposed project is likely to have minimal or no adverse environmental impacts") in the sense that no forced land acquisition or negative resettlement impacts on indigenous peoples were associated with the project. Given that the construction and operation activities were seaward from the south end of the Colombo Port, no land was additionally required by either the government or the private sector. With regards to its environmental impacts, the project did not result in negative evaluations as ambient air quality was within the 2004 baseline reference and the majority of the water quality parameters was back to baseline references (as of June 2014).

Alongside positive successes in the project, the Report and Recommendation of the President (RRP) pointed out the need to avoid the imminent capacity constraint of the Colombo Port as the rationale of the project. In general, every port has three physical facilities of (1) sufficient and safe waterway and ship-turning basin; (2) quay and wharf including loading and unloading facilities; and (3) shipyards connected to land transport. The RRP proposed a solution plan to meet those three facility requirements by recommending two major complementary measures - investments in waterway and container-handling equipment, and the enhancement of efficiency through PPP arrangements. Balanced investments in three facilities were essential for the effective port business management, but it was not clear how the project was able to achieve the enhancement of capacity and efficiency (ADB 2016a).

Incorporating a wide range of international best practices, the project ultimately aimed at establishing the landlord status of the SLPA and entrusting the operation to the private sector to improve efficiency. However, such aims turned out to be very challenging, particularly in terms of risk management. To 
mitigate a risk to the project, the loan covenant stipulated a specific clause that selecting a successful bidder for private concessionaire was a condition of loan effectiveness. Nevertheless, it was amended so arbitrarily that breakwater construction was commenced without prior selection processes of the private concessionaire. As a result, the project completion report neither evaluated whether the condition for the prior selection was needed nor stated how the project was affected by its waiver (ADB 2016a).

\section{PROSPECT OF SRI LANKA'S PPP: CHALLENGES AND PROPOSALS}

Regarding the above-mentioned analyses of the two port expansion projects as key bases of Sri Lanka's PPP in infrastructure, we now discuss how to further develop and strengthen the quality of Sri Lanka's PPP afterwards. In 2016, ADB and SLPA signed a new agreement for 500 million USD port development project via PPP, but this new agreement has been immediately stuck in the impasse of slackened implementation. An investigation of key complexities revolving around Sri Lanka's PPP projects leads us to ascertain chronic challenges and possible improvements to weaken them.

\section{The East Container Terminal of the Colombo Port}

The East Container Terminal (ECT), as shown in figure 5, is a hitherto crucial part of the Colombo Port as it acts as the SLPA's key strategic point for trans-shipment for global and regional trade (SLPA 2017). The ECT, as the second terminal in the South Harbour, has constantly received large sums of investment. In recent times, ADB and SLPA signed a transaction advisory agreement in 2016 to develop the ECT through PPP (Infrapppworld 2016). The SLPA invested 80 million USD in constructing the 400-meter berth, and ADB provided 300 million USD loan in 2008 to support other constructions such as the breakwater (ADB 2017). Hence, the development of the entire terminal was expected to cost 500 million USD with the majority invested into container yard, terminal buildings and facilities. With $\mathrm{ADB}$ appointed as an intermediary to assist Sri Lanka in transaction advisory services during the process of selecting the concessionaire, the SLPA issued an Invitation for EOI in June 2016 to select the private concessionaire. 


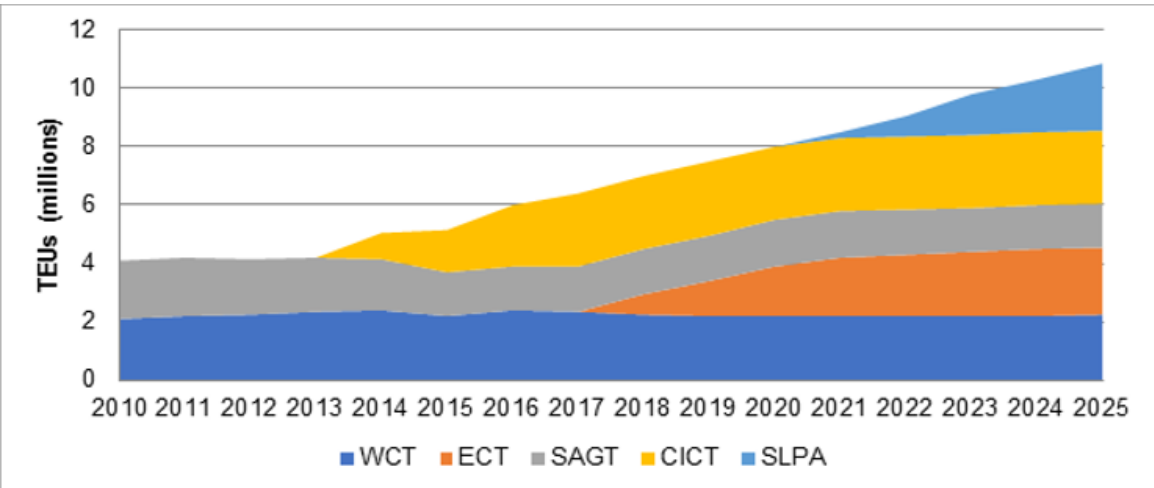

CICT: Colombo International Container Terminals Ltd.; ECT: East Container Terminal; SAGT: South Asia Gateway Terminal Ltd.; SLPA: Sri Lanka Port Authority; WCT: West Container Terminal.

Source: SLPA (2017).

\section{FIGURE 6. TRAFFIC FORECAST OF EACH TERMINAL OF THE COLOMBO PORT}

The traffic for the Colombo Port has grown over $8 \%$ in terms of compounded annual growth rate over the last 20 years, which implies that PPP has reinforced productivity for trans-shipment (Department of External Resources 2016). Indeed, figure 6 reconfirms how rapidly ECT is expected to grow in terms of traffic since 2016 in comparison to other terminal operations and the ECT, thereby, offers great investment opportunities for the private sector. In response to the growing investment opportunities, the private concessionaire is expected to gain high level of return on investment by deploying container handling equipment upfront and operating existing facilities. Furthermore, the concessionaire would be able to collect fees of the port use and have the benefit of tax exemptions in order to cover the operation and maintenance cost of the terminal throughout the 35-year contract (SLPA 2017).

The constructive relationship between the public and private entities would be crucial in harnessing the terminal into a strategic hub for regional trade with the retention of $51 \%$ control of the ECT by SLPA. The SLPA is not a novice in this field in the sense of having previous experiences in dealing with bids by the concessionaires as a BOT; nevertheless, this 2016 agreement is seen as a new challenging development compared with the previous occasions (DESARAM 2016). The ADB as a new player in advising the SLPA with this bankable PPP project can "create a new template for structuring and delivering PPPs in Sri Lanka," according to Head of ADB's Office of PPP Ryuichi Kaga (Noda 2016). However, the addition of ADB may pose new challenges to the government of Sri Lanka, as issues of communication, policy coherence and management of the ECT - particularly, in its present form of $440 \mathrm{~m}$ long and $18 \mathrm{~m}$ deep quay wall need to be addressed. In consequence, the project is currently in stalemate, with 
no major advances since inaugurating of the project in 2016. This current case alongside two other Port cases indicates that an alternative PPP framework needs a strong regulatory mechanism and a clear stakeholder mapping to avoid stakeholder conflicts or issues of accountability.

\section{Key Challenges to Sri Lanka's PPP}

From the two cases examined in the previous section, it is clear that main points of success in Sri Lanka's PPP infrastructure projects encompass Sri Lanka's trade competitiveness, foreign direct investments and jobs created. However, it must be also noted that these cases indicate how Sri Lanka's PPP needs improvement, especially in monitoring and evaluation during and after project implementations. For both cases, feedback appraisal fell short mainly due to the lack of a specialised unit that would have overseen and monitored the progress of projects or at least acted as a mediator between the Sri Lankan government and the private sector (ADB 2016a). Without the government's institutional efforts to meet internationalised standards for PPP, perfunctory reviews on infrastructure projects, which we witnessed the two Colombo Port cases, would mechanically generate positive results by passing over uncomfortable problems that should be mended.

In economic regards, PPP provides a wide range of benefits for the implementing nation. For the Sri Lankan government, PPP is becoming an increasingly favoured strategy for infrastructure development because of increased capital availability for a project; with enhanced management skills, improved delivery time; and cost-effective operations (Department of External Resources 2013). Despite these potential benefits, in structural senses, the government of Sri Lanka at times found it difficult to 'benchmark' some of the international best practices. In order for PPP to succeed, more emphasis must be given on the latter stages of implementation, which are monitoring and evaluation in tandem with effective risk management and the enabling business climate. With constrained budget and fragile PPP frameworks, it is difficult for developing countries to comply with international standards for better implementation.

Indeed, the government of Sri Lanka has strongly emphasised the port expansion via PPP schemes as examined throughout the previous case studies (National Agenda Committee 2016). Given that one of the most crucial sectors in Sri Lanka's PPP in infrastructure has been long regarded as transport especially, ports (construction and services) due to the fact that Sri Lanka's economy relies mainly on trade, the government has endeavoured to reflect international best practices into its reformative actions to introduce a better enabling environment for PPP. From the port cases, we now know that the government of Sri Lanka, while realizing the importance of PPP, has made 
several changes to its ministerial units and divisions for the betterment of the enabling environment for institutional regulation and maturity (Economist Intelligence Unit 2018). The new PPP unit should provide a rigorous platform to facilitate some PPP schemes. However, there are some challenges that must be identified in order for the country to improve its PPP schemes to the international standards for PPP implementations.

\section{1) Financial Deficiencies in the Enabling Business Climate}

As mentioned briefly in the introduction, a significant challenge to Sri Lanka's economy is the low level of public revenue collection aggravated by high debt-to-GDP ratio, indicating the unstable nature of the government's finances. This further suggests that sustaining public investment in infrastructure and public service provision has been restricted in Sri Lanka. Thus, PPP would be a feasible option for the government of Sri Lanka. However, if the weak financial posture is not addressed sufficiently, private investments, especially foreign investments, would protract their involvements in Sri Lanka. The capital market therefore needs rejuvenating; with a thin capital market, it is difficult for the Sri Lankan government to raise both equity and debt capital to fund PPPs (ADB 2016b). As a result, foreign investors often request the government to provide guarantees on the bankability of projects in the form of taxation structures, sale rates and foreign exchange remittance.

Furthermore, with a strengthened capital market, not only can the government of Sri Lanka can attract more foreign investors. Social support can also be gained, which is "based on the public acceptance of the concept of private provision" (Li et al. 2005, 466). As depicted in the Colombo Port Development Project in 1999, QEQ employees were offered contracts to work for SAGT, but the majority initially declined the offer due to their sceptical stances on PPP as the economy was vulnerable at the time (UNDP 2007). Extenuating circumstances such as high inflation, and unfavourable exchange and interest rates are also deemed as challenges in adopting PPP. As Kumaraswamy and Zhang point out those PPPs in developing countries are at times costlier than projects in developed countries, the Sri Lankan government needs to provide a favourable economic climate for PPP to develop (Kumaraswamy and Zhang 2001).

\section{2) Regulatory Frameworks}

Regulatory frameworks include government institutions such as ministries and units as well as government laws, regulations and policies. The features of regulatory frameworks are largely dependent on the country's economic and political conditions, and hence, frameworks differ systematically across countries (Lobao and Kraybill 2005). In Sri Lanka, the government first introduced its 
national policy document in 1992 that mentioned PPP framework as a tool for infrastructure development. However, it did not address some core aspects of PPP including value for money, risk allocation and public component. The 1998 PPP Guidelines Part II triggered the establishment of PPP-related institutions, albeit most have been rather inactive with the exception of units within the Ministry of finance such as the BOI, and project based divisions such as Cabinet Appointed Negotiation Committee and the Project Committee.

Despite these efforts to enhance national PPP frameworks, an act that governs PPP legally is required. The 1998 Guidelines failed to secure the legally-binding control of public authorities, thereby discouraging private investments and arrangements in the long-term, although in the short-term, contractual arrangements can be made. The presence of regulatory frameworks that meet the international standards would promote confidence in investors and dispute settlement with efficacy. The Government Procurement Guidelines of 2007 replaced the Guidelines established in 1998. However, the 2007 Guidelines also failed to have legally binding effects, similar to its predecessor. Despite these caveats, the 2007 Guidelines do provide a basis for the government to improve on. Its section 8.14.1 accords the force majeure or casus fortuitous clause, and sections 5.4.14, 5.4.15 and 5.4.16 issue dispute resolution mechanisms with international arbitration rules such as the Rules of Arbitration of the International Chamber of Commerce or the United Nations Commission on International Trade Law for foreign funded projects (World Bank 2017). Moreover, in 2015, creating the National Procurement Commission (NPC) through the $19^{\text {th }}$ Amendment to the Sri Lankan Constitution enabled the promotion of an investment climate that could be more transparent, equitable and at the same time competitive. Despite the NPC not directly referring to PPP, it indicated the government's intent to foster infrastructure development. 4

\section{3) Cultural Adaptations}

Given the nature of PPP holding private concessionaire to work together with local public contractors, as Minogue pointed out, "the application through practical reform programs will encounter problems of adaptation to complex cultural systems" (Minogue 2004, 173). It is a strenuous job for the government to perfectly tailor developed countries' PPP models. Considering Sri Lanka's economic and social complexities, implementing PPP is much more challenging. Thus, in order to align PPP schemes as well as integrate efforts from different departments that deal with PPP-related projects, the new PPP unit was established through a Cabinet decision in January 2017. This unit came under the Ministry of Finance and has been guided by the World Bank. Furthermore, the unit was unveiled via the Sri Lanka Investment and Business Conclave 2017, which aims 
to attract foreign investors and business partners for exports from more than 20 countries (Ceylontoday 2017). The PPP unit would ensure that this process for finding a right foreign partner would be done in a globally accepted manner with priority in energy, infrastructure and transport, especially regarding the development of port facilities in order to enhance the competitiveness of the nation's trade, and ultimately ease the balance of payment. Although the new PPP unit may have similar duties as the BOI, the significant difference stems from the fact that the BOI deals with private investments not requiring partnerships and therefore the two units are complementary to each different function.

\section{Possible Improvements for Sri Lanka's PPP framework}

Albeit serious challenges that the government of Sri Lanka has been facing, there is a set of policy recommendations that can be used as a solution mechanism to the ills regarding PPP frameworks. Hence, this section outlines some of the key policy improvements and recommendations that have been suggested by international organisations including multilateral development banks and bilateral aid agencies such as USAID (Economy Next 2017). These policy recommendations may guide Sri Lanka in constructing a PPP framework that meets the internationally accepted standards and follows the global best practices.

First of all, PPP is primarily about building strong relationships between stakeholders. Therefore, the notion of capacity building or capacity development is salient in PPP arrangements. In Sri Lanka's case, especially through the Port expansion projects, relationship with ADB has been established. Such established relationship needs to be strengthened further by the Sri Lankan government identifying potential PPPs that are consistent with the overall policy of the country. The government must articulate "strategic justification" for potential projects in terms of viability and bankability (ADB 2012b, 10). ADB has existing initiatives such as the Multilateral Public-Private Partnership for Infrastructure Capacity Development (MP3IC) and the Asia PPP Network, which can ensure that country's efforts in developing infrastructure through PPP framework are both efficient and effective.

As a result, for the Asia-Pacific region, the ADB (2008) proposed the 'New Long-Term Strategic Framework of ADB 2008-2020' which identified PPP is a vital modality to achieve economic growth in the region. Table 1 demonstrates how the structure of the ADB's results framework is organised; this framework is intricately linked to the organisation's plans to strengthen regional PPP frameworks. By using four levels of results, ADB can attest to the credibility of Sri Lanka's PPP projects in terms of how it fits with international standards set via good governance. Such a four-pillar PPP operational framework that the ADB 
designed provides a solid foundation for the Sri Lankan government to work with. Utilizing this framework enables the country to develop a congruent set of PPP policies, and in doing so, hiring a PPP specialist or advisors may be necessary. Capacity building and knowledge sharing activities between the ADB and the government of Sri Lanka are vital steps in enhancing the country's PPP schemes.

\section{TABLE 1. STRUCTURE OF ADB'S RESULTS FRAMEWORK}

\begin{tabular}{l}
\hline Indicators \\
\hline Level 1: Asian-Pacific Outcomes \\
\hline Millennium Development Goals \\
GDP, infrastructure, business environment, governance and trade \\
\hline Level 2: Contribution to Country Outcomes: Key Outputs \\
\hline Transport \\
Energy \\
Water \\
Education (at all levels) \\
Finance \\
\hline Level 3: Operational Effectiveness \\
\hline Operational quality and portfolio performance \\
Finance mobilisation \\
Knowledge development \\
Partnership \\
\hline Level 4: Organisational Effectiveness \\
\hline Use of Human resources \\
Use of budgetary resources \\
Business processes and practices \\
\hline Source: ADB (2016).
\end{tabular}

Source: ADB (2016b).

Some measures have already been undertaken by the government of Sri Lanka in order to reinforce its PPP schemes. The biggest step forward was recently marked by the establishment of a new PPP unit as discussed earlier. Although numerous infrastructure projects have been done in the form of PPPs, Sri Lanka as a country is still not good at the international standards for PPP implementations in comparison to most of the advanced countries or even neighbouring countries like India. The PPP unit, established in January 2017, currently has 17 staffs with a chief operating officer and directors for the economic, finance and compliance division. The outcome of this newly formed unit is yet to be seen as it was only mid-May when the unit had a full team functioning (PPP Knowledge Lab 2017). The core objectives of this unit are in broad terms to facilitate and integrate PPP efforts, and more specifically, to liaise with potential investors on a daily basis to assess bankable projects, which lead the Unit to hire staffs who have private sector backgrounds. This new unit would be the cornerstone of the country's PPP policy with the expectation that it begins 
to resemble some of the advanced countries in PPP, where an autonomous PPP unit functions.

TABLE 2. NEW FRAMEWORK IN FOREIGN FINANCING

\begin{tabular}{l|l}
\hline \multicolumn{1}{c|}{ From } & \multicolumn{1}{c}{ To } \\
\hline Project based funding & Budget support based on program based funding \\
\hline Isolated projects stand apart without synergy & $\begin{array}{l}\text { More focused \& coordinated programs towards a } \\
\text { common goal }\end{array}$ \\
\hline $\begin{array}{l}\text { Planning \& designing outsourced with high } \\
\text { consultancy cost }\end{array}$ & $\begin{array}{l}\text { In-house planning \& design process leading to } \\
\text { improved domestic capacity }\end{array}$ \\
\hline $\begin{array}{l}\text { Funding is not based on performance } \\
\text { Procurement guidelines of development partners } \\
\text { apply }\end{array}$ & $\begin{array}{l}\text { Performance based disbursement } \\
\text { preference for domestic contractors }\end{array}$ \\
\hline $\begin{array}{l}\text { Long preparation time with high administration } \\
\text { cost }\end{array}$ & $\begin{array}{l}\text { Short preparation time with low administration } \\
\text { cost }\end{array}$ \\
\hline
\end{tabular}

Source: Department of External Resources (2014).

Complementary to the changing dynamics of the country's PPP institutions, the Sri Lankan government has been taking initiatives to align future foreign borrowings with sector development programs through a program-based approach of budget support. Such scheme for foreign financing would provide more effective structures for reinforcing mutual accountability between development partners and recipients, ultimately, strengthening the capacity of implementing agencies (multilateral development banks or bilateral agencies) to manage foreign finance based projects (see table 2). At a broader level, the government and ADB worked on the Country Partnership Strategy in accordance with Mahinda Chinthana: Vision for the Future for the macroscopic purpose of integrating the PPP unit, the program-based framework for foreign borrowings, and closer partnerships for all parties involved (Ministry of Finance and Planning 2010).

Moreover, as already highlighted, the regulatory framework is one of the main deficiencies of Sri Lanka's PPP framework. Therefore, a dedicated PPP act with regulations that would clarify and stabilise the PPP functionality is required element for reforming current institutional settings for implementing PPPs. According to USAID (2016), an explicit legal framework dealing with PPP would give investors confidence, and enable PPP processes to become more transparent; overall, a legal framework would provide credibility. The first step towards the improvement of regulatory frameworks would be amending and upgrading the 1998 and 2007 Guidelines, possibly via 'Swiss Challenge', where "an innovative unsolicited proposal made by a firm to the government is made public" (Economy Next 2016). The newly established PPP unit can be incorporated in the Guidelines regarding the formal approval for prospective projects that must provide a clear set of criteria and the evaluation of affordability, value for money, 
economic viability, and legal and social feasibility. A legal framework that follows the international standard and guidelines should incorporate mechanisms of payment (how the repayment of the infrastructure investment is done); investor's rights and lenders' rights; dispute management or settlement; investment promotion (viability gap funding, tax incentive and concession periods) and finally, governance of projects (Perera 2016).

Last but not least, contractual arrangements must be strengthened by including technical parameters (minimum requirements and prerequisites regarding design, construction and investment of the project with milestones); concession period (the time needed to recoup the investment); concessionaire rights and obligations (to avoid disputes between stakeholders, and clarify responsibilities); concession fees that consider profit maximisation for PPP partners and provide sufficient public welfare; and the risk-benefit allocation that denotes how stakeholders are accountable for certain activities. Although the most important stakeholders are the public and private sectors, other stakeholders must be considered for an enhanced PPP framework. Civil societies in Sri Lanka are limited in terms of playing a role in an advocacy capacity over budget planning, devising strategies, and especially, monitoring and evaluation of PPP projects (USAID 2016). The complexity of government actions and obscurity of government's strategic plans result in sidelining the proactive engagement of the civic sector in PPP-related projects. Several points offered here are not to deliver remedies to the current situation on PPP, but rather, provide triggering points in enhancing Sri Lanka's PPP frameworks.

\section{CONCLUDING REMARKS}

Sri Lanka is currently in a transitionary period in terms of economic and social development. Albeit some social issues regarding ethnic minorities, internal conflict has been subdued since 2009, and the country has been experiencing rapid economic growth. At the centre of such surge, infrastructure development particularly for energy, transportation, water supply and sanitation has been playing a prominent role (World Bank 2017). Thus, improved infrastructure underpins future development plans and enables the government to address numerous social and economic issues. However, government capacity in regard to funding infrastructure projects is limited with high debt rates and a rather fragile financial market that heavily relies on concessional loans from multilateral banks and foreign investments. As a way to enhance infrastructure without hampering government control, PPP has been a popular scheme with the support and guidance from experienced international institutions such as the ADB and the USAID.

One of the most influential yet intriguing PPP projects was the strategic 
expansion of the Colombo Port. The two largest projects were examined in this study to demonstrate how Sri Lanka's PPPs functioned, and what impacts the schemes engendered. The Colombo Port is still the economic hub of Sri Lanka as it has been playing a crucial role in regional trade flows. Expanding the Port by constructing new terminals and enabling the private sector to efficiently operate them over the contractual period in the form of BOT fostered the growth of Port capacity and container traffic (Sri Lank Treasury 2010). In terms of pure output and outcome, these PPP projects were rated by the ADB as 'excellent.' It is easy to conclude that the two Colombo Port expansion projects generated more success points than failures. However, this cannot be inferred as 'no room for improvements' if we take a close look at the scratch beneath the surface and the true impact of the Colombo Port PPP infrastructure projects. These two cases indicate what factors the government should consider when managing the project on the ECT construction project that is now caught in stalemate.

Since 2016, the government of Sri Lanka has been endeavouring to negotiate with numerous potential private concessionaires to continue the construction of the ECT via PPP, and more importantly, operate the terminal for a 30 -year period. Former projects show that despite the significant improvements in efficiency of the port operation, it is arduous to make the management of PPP projects more sustainable. Numerous stakeholders come into play, and the possible scenario of PPPs for the ECT construction would be beyond a mere arrangement between the public and private sectors.

Normally, international best practices of PPP follow the global standards and regulations from phase one of PPP development to the last phase. One of many options to enhance current PPP frameworks would be to 'benchmark' some of the most advanced PPP models. Sri Lanka should look upon these practices and tailor them so that they can construct their own effective PPP frameworks. However, there are some obstacles including financial deficiencies, the lack of rigorous PPP regulations, and the complexity of cultural adaptations. In addition, extenuating or unprecedented circumstances may shape the outcome of government initiatives. Albeit such potential challenges in strengthening the PPP framework, the newly established PPP unit would provide a solid platform to facilitate partnerships, especially in the infrastructure sector.

In a nutshell, this study provides a meaningful outlook on Sri Lanka's PPP using Colombo Port cases to identify how PPPs are being utilised, and to what degree the country's PPP schemes need reinforcing. It focuses on the Port infrastructure development, which provides a platform for future research on different fields such as energy and utility. By looking into other fields and merging some of the core findings would provide broader picture of the future prospect of Sri Lanka's PPP framework. 


\section{REFERENCES}

Alfen, Hans Wilhelm. 2009. "Public Private Partnership (PPP) as Part of Infrastructure Management Solutions: A Structural Approach of Delimiting PPP from Other Private Sector Participation Models." Paper presented at $18^{\text {th }}$ CIB Building Congress, Salford, United Kingdom. May 2010. https://www.irbnet.de/daten/iconda/CIB_DC24063.pdf.

Alfen, Hans Wilhelm et al. 2009. Public-Private Partnership in Infrastructure Development: Case Studies from Asia and Europe. Weimar: BauhausUniversity.

Appuhami, Ranjith, Sujatha Perera and Hector Perera. 2011. 'Coercive Policy Diffusion in a Developing Country: The Case of Public-Private Partnerships in Sri Lanka." Journal of Contemporary Asia 41(3): 431-451.

ADB. 2005. Equity Investment and Loan to the Colombo Port Development Project in the Democratic Socialist Republic of Sri Lanka. Mandaluyong City: ADB.

ADB. 2008. The Long-term Strategic Framework of the Asian Development Bank 2008-2020. Mandaluyong City: ADB.

ADB. 2012a. Public-Private Partnership Operational Plan 2012 -2020. Mandaluyong City: ADB.

ADB. 2012b. The Asian Development Bank's Support for the Transport Sector in

Sri Lanka. Independent Evaluation. Mandaluyong City: Independent Evaluation/ADB.

ADB. 2015. Colombo Port Expansion Project: Completion Report. Mandaluyong City: ADB.

ADB. 2016a. Colombo Port Expansion Project: Validation Report. Mandaluyong City: ADB.

ADB. 2016b. Country Assistance Program Evaluation. Independent Evaluation. Mandaluyong City: ADB.

ADB. 2017. ADB Sings Co-advisory Agreement with SMBC for East Container Terminal, Colombo Port. Mandaluyong City: ADB.Ceylontoday. 2017. New PPP Unit to be Launched at Sri Lanka Investment Conclave. Ceylontoday. http://www.ceylontoday.lk/print20170401CT20170630.php?id=21789.

Cook, Paul, Colin Kirkpatrick, Martin Minogue and David Parker (Eds.). 2004. Leading Issues in Competition, Regulation, and Development. Cheltenham: Edward Elgar.

De Saram, Savantha and Jivan Goonetilleke. 2017. "Sri Lanka Getting Deal through Ports Terminals 2017." DESARAM. http://desaram.com/wp-content/ uploads/2017/03/SRI-LANKA-Getting-the-Deal-Through-Ports-Terminals -2017-edition.pdf.

Department of External Resources. 2013. Global Partnership towards Development. 
Colombo: Ministry of Finance and Planning.

Department of External Resources. 2014. Performance Report. Colombo: Ministry of Planning, Economic Affairs, Child, Youth and Cultural Affairs.

Department of External Resources. 2016. Performance Report. Colombo: Ministry of Planning, Economic Affairs, Child, Youth and Cultural Affairs.

Economist Intelligence Unit. 2018. "Measuring the Enabling Environment for Public-Private Partnerships in Infrastructure." http://infrascope.eiu.com/.

Economy Next. 2016. "Sri Lanka to Adopt Swiss Challenge Process for Unsolicited Proposals." Economy Next. August 10, 2016. http://www.economynext.com/

Sri_Lanka_to_adopt_Swiss_Challenge_process_for_unsolicited_proposal s-3-5826.html

Economy Next. 2017. "US Helps Sri Lanka Do PPP National Policy, Regulations." Economy Next. September 26, 2016. http://www.economynext.com/US helps_Sri_Lanka_do_PPP_national_policy,_regulations-3-6204-1.html.

Evans, Mark. 2009. "Policy Transfer in Critical Perspective." Policy Studies 30(3): 243-268.

Infrapppworld. 2016. "Colombo Port - East Container Terminal."

http://www.infrapppworld. com/documents/projects/project-brief-43.pdf.

Economist Intelligence Unit. 2017. "The 2015 Infrascope: Evaluating the Environment for Public Private Partnerships in Africa."

https://www.eiu.com/public/topical_report.aspx?campaignid=AfricaInfras cope2015.

IBRD. 2017. "Public-Private Partnerships." Washington, D.C.: World Bank.

Kim, Taekyoon and Sojin Lim. 2017. "Forging Soft Accountability in Unlikely

Settings: A Conceptual Analysis of Mutual Accountability in the Context of South-South Cooperation." Global Governance 23(2): 183-203.

Kumaraswamy, M. M., and Xueqing Q. Zhang. 2001. "Governmental Role in BOT-led Infrastructure Development." International Journal of Project Management 19(4): 195-205.

Li, Bing, A. Akintoye, P. J. Edwards Corresponding Author and C. Hardcastle. 2005. "Critical Success Factors for PPP/PFI Projects in the UK Construction Industry." Construction Management \& Economics 23(5): 459-471.

Lobao, Linda and David S. Kraybill. 2005. "The Emerging Roles of County Government in Metropolitan and Nonmetropolitan Areas: Findings from a National Survey." Economic Development Quarterly 19(3): 245-259.

Ministry of Finance and Planning. 2006. Mahinda Chinthana: Vision for a New

Sri Lanka - A Ten Year Horizon Development Framework, 2006-2016.

Colombo: Government of Sri Lanka.

Ministry of Finance and Planning. 2010. Mahinda Chinthana: Vision for the Future. Colombo: Government of Sri Lanka.

Ministry of Ports and Shipping. 2016. Invitation for Expression of Interest for 
Prequalification to Bid for the Development of East Container Terminal of Port of Colombo. Colombo: Ministry of Ports and Shipping.

Narangoda, B. Himalika and A. Khathibi. 2014. "Public Private Partnership in Healthcare Industry in Sri Lanka as an Alternative to Privatization." International Journal of Management and Business Research 4(2): 95-106.

National Agenda Committees. 2016. Private Public Partnerships to Catalyze Infrastructure Development in Sri Lanka. https:/www.chamber.lk/wpcontent/uploads/2017/04/NAC-PPP-Note-FINAL-September-2016_v6.pdf.

Noda, Tomas S. 2016. “ADB, Sri Lank Ports Authority Ink Agreement for $\$ 500 \mathrm{~m}$ Port Project via PPP.” Deal Street Asia. February 24, 2016. https:/www. dealstreetasia.com/stories/adb-sri-lanka-ports-authority-ink-agreement-for -500m-port-project-via-ppp-31881/

Perera, W. S. L. 2016. "Public Private Partnership for Infrastructure Development." SSRG International Journal of Civil Engineering 10(3): 6-9.

PPP Knowledge Lab. 2017. Sri Lanka | PPP Knowledge Lab. https://pppknow -ledgelab.org/countries/sri-lanka.

Rashed, Abu, Fahim Faisal and Husne Ara Shikha. 2012. Fiscal Risk Management for Private Infrastructure Projects in Sri Lanka. http://www.cbsl.gov.lk/pics n_docs/10_pub/_docs/IRC/2012/Fiscal_Risk_Management_full.pdf.

Sharma, Chandan. 2012. "Determinants of PPP in Infrastructure in Developing Economies." Transforming Government: People, Process and Policy 6(2): 149-166.

Simmons, Beth A. and Zachary Elkins. 2004. "The Globalization of Liberalization: Policy Diffusion in International Political Economy.” American Political Science Review 98(1): 171-189.

SLPA. 2017. Sri Lanka Ports Authority. http://portcom.slpa.lk/East_container terminal.asp? $\mathrm{chk}=6$.

Sri Lanka Treasury. 2010. Private Sector Infrastructure Projects. Colombo: Government of Sri Lanka.

Sri Lanka Treasury. 2017. Welcome to PPP Unit of Sri Lanka. Retrieved from http://www.ppp.treasury.gov.lk/index.php/welcome-to-ppp-unit-of-sri-lank a. Traupel, Tobias. 2009. "PPP in the Current Financial Situation: Challenges and Chances." European Procurement \& Public Private Partnership Law Review 4(2): 6-12.

UN. 2003. "Private Sector Participation in the Transport Sector." New York: United Nations.

UNDP. 2007. "Public-Private Partnerships: Case Studies for Sustainable Development

- Colombo, Sri Lanka Case Study (Port Expansion).” http://unossc1.undp. org/GSSDAcademy/SIE/Docs/Vol15/11Sri\%20Lanka.pdf.

USAID. 2016. 'Report on Sri Lanka's Current PPP Environment and Recommendations 
for Future PPP Strategy: Leadership in Public Financial Management II (LPFM II)." Washington, D.C.: USAID.

World Bank. 2010. "Procurement Arrangements Applicable to Public-Private Partnerships (PPP) Contracts Financed under World Bank Projects: Guidance Note." Washington, D.C.: World Bank.

World Bank. 2015. "2015 South Asia (SAR) PPI1 Update." http://ppi.worldbank.org/ /media/GIAWB/PPI/Documents/Data-Notes/SAR-Update-2015.pdf.

World Bank. 2017. "Public Private Partnerships on Public Financial Management Reforms in Asia: Other Financial Accountability Study. https://elibrary. worldbank.org/doi/abs/10.1596/26657.

\section{ENDNOTES}

1 Sri Lanka is an island nation in the Indian Ocean with a population of just over 20 million. Since the end of the internal conflict in 2009, the country has performed strongly in terms of economic growth and development. Thus, the World Bank (2017) categorises the country as a lower-middle-income country with a per capita gross domestic product (GDP) of 3,800 USD. Currently, the country is in a transitionary period following the presidential election in 2015, where the new coalition government - the National Government of Consensus - has objectified the issues of human development and social inclusion under the leadership from president, Maithripala Sirisena. The two issues have been predominantly included in the National Policy Statements and the National Strategic Plans. The main reason for this is the 'profligate borrowings' by the previous governments that were vulnerable to even minor economic disruptions.

2 Two data gathering methodologies - primary and secondary data - were implemented to the study. First, interviews were conducted with relevant personnel, ranging from specialists that were heavily involved in some of the Colombo Port cases to administrative staffs within ADB. In addition, an in-depth interview was conducted with one of the directors of the newly established PPP unit. The rationale for this interview was to ascertain the features and raison d'être of the unit, which is anticipated to influence Sri Lanka's PPP strategies in the future. Second, secondary data were extensively utilized to diagnose Sri Lanka's current socio-economic condition for PPP strategies, and some sources were used to verify the validity of some of the primary data. Main secondary sources were publications of governmental organizations such as the Ministry of Finance, and reports from multilateral organizations - ADB, World Bank and UNDP - such as the evaluation report of relevant cases.

3 The Infrascope compares the enabling environment for PPPs across 40 developing 
countries by the different scale of measurement: mature (80-100); developed (60-79); emerging (30-59); and nascent (0-29).

4 On top of Sri Lanka's regulatory efforts, the U.S., as a key donor country, is prepared to assist Sri Lanka in reinforcing its national policy and strategy on PPP (Economy Next, 2017). With USAID as the spearhead, a roadmap - to assess the current legal and regulatory environment of PPP in comparison to the international best practices - is being devised. Hence, it is anticipated that Sri Lanka's regulatory framework would improve. Nevertheless, since these efforts are being implemented recently, impact is yet to be seen, and policy and legal aspects of national PPP schemes are still the main deficiencies that government must tackle. 